\title{
舌痰状癌例
}

\author{
坂本 雅之・新正由紀子・肥後隆三郎
}

\section{A Case of Verrucous Carcinoma of the Tongue}

\author{
Masayuki Sakamoto, Yukiko Shinjo and Ryuzaburo Higo
}

(Tokyo Metropolitan Hiroo Hospital)

\begin{abstract}
We report a case of verrucous carcinoma of the tongue. A 73-year-old female noticed leukoplakia of the right edge of her tongue. As a hard mass appeared in that area, partial resection of the tongue was performed. Histopathological study revealed that the intraoperative specimen was epithelial hyperplasia with moderate dysplasia. The patient was carefully followed. About half of one year later, the hard tumor reappeared. Partial resection of the tongue was performed again, and this time, histopathological study revealed that the tumor was verrucous carcinoma.
\end{abstract}

Key words : verrucous carcinoma, tongue, histopathological study, CT examination

\section{はじめに}

疮状癌 (verrucous carcinoma) は1948年に初めて Acker$\operatorname{man}^{1)}$ によって報告された悪性度の低い高分化型の扁平 上皮癌の一亜型と考えられている. 口腔粘膜に最も多く みられ，粘膜白板症に合併することが多い。

今回, われわれは舌病状癌を治療する経験したので文 献的考察を加えて報告する.

\section{症 例}

症例 : 73 歳, 女性.

主訴：舌の白斑.

既往歷: 20 歳時急性虫垂炎, 46 歳時肝機能障害, 48 歳時胆石, 53 歳時高血圧, 62 歳時白内障・大腸ポリープ 切除術, 63 歳時狭心症, 64 歳時片頭痛.

現病歴：以前から義歯により常時舌が擦られていた。 平成 14 年 1 月末より舌の白斑が出現し, 消退しないた め, 平成 14 年 8 月 28 日東京都立広尾病院耳鼻咽喉科を 初診した. 初診時, 舌右縁表面に白板を伴っていたが硬 結は認められなかったため, 舌白板症として経過を観察 していたが, 硬結が触知されるようになった。造影 CT にて, 舌右側に不整に濃染される領域を認めた（図 1).
生検, 根治目的に 10 月 16 日, 舌部分切除術を施行した. 触診にて腫瘍の位置を確認しながら約 $5 \mathrm{~mm}$ のマージン をつけて切除した. 摘出標本は病理組織学的に炎症性変 化が目立ち，軽度異型性を伴う上皮の過形成と診断され た（図 2)。退院後経過を観察していたが，平成 15 年 3 月頃より切除面が硬く隆起するようになった. 造影 CT にて, 舌右側, 前回手術にて切除された領域の辺縁に不 整に濃染される領域を認めたため（図 3 ), 白板症の悪性 腫瘍への移行と考えられた。頸部リンパ節転移は認めら れなかったため, 4 月 14 日全身麻酔下で舌右側半切除術 を施行した. 病理組織学検査にて, 早期浸潤を伴う病状 癌と診断された（図 4). 放射線治療は行わなかった。 術 後 1 年が経過したが, 再発は認めていない.

\section{考 察}

疮状癌は病理組織学的には異型の低い扁平上皮が乳頭 状増殖を示し, 角化の強い大きな葉状の突起を作り, 悪 性度の低い高分化型の扁平上皮癌の一亜型とされてい る. 口腔粘膜に最も多くみられるが, 喉頭, 食道, 陰茎, 外陰, 臸, 子宮頸部, 肛門, 足蹠の皮膚などにもみられ る. 組織像の特徵として, 組織表面からは悪性所見は認 


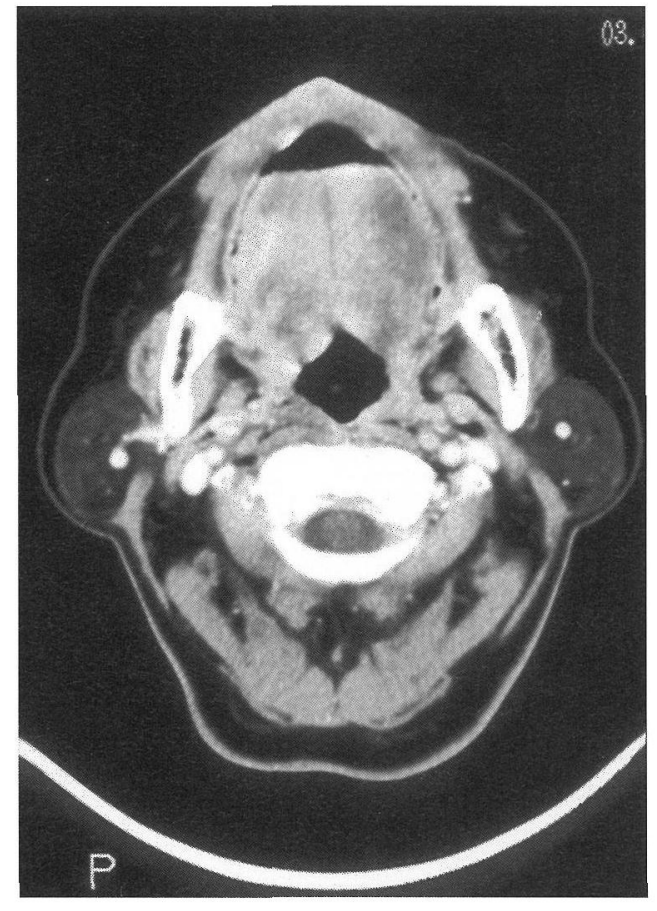

図 1 初回手術前の造影 CT 舌右側に濃染される不整な領域を認めた。

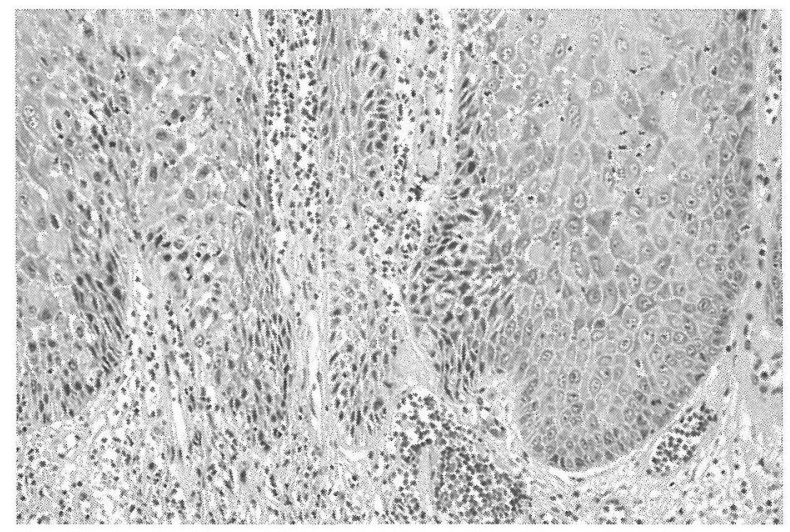

図 2 初回手術標本の HE 染色 ( × 50)

軽度異型性を伴う上皮の過形成と診断された。

められず組織深部に悪性所見を認めるため，浅部のみを 生検すると乳頭腫，角質増殖症，ケラトアカントーマな どと䛊診されることがあり，疮状癌は病理組織診断が困 難なことが多い1)。われわれの症例でも，最初に行った 舌部分切除術は腫瘍を約 $5 \mathrm{~mm}$ のマージンを付けて切除 したにもかかわらず，軽度異型性を伴う上皮の過形成と 診断されるにとどまり，その後，残存したと思われる部

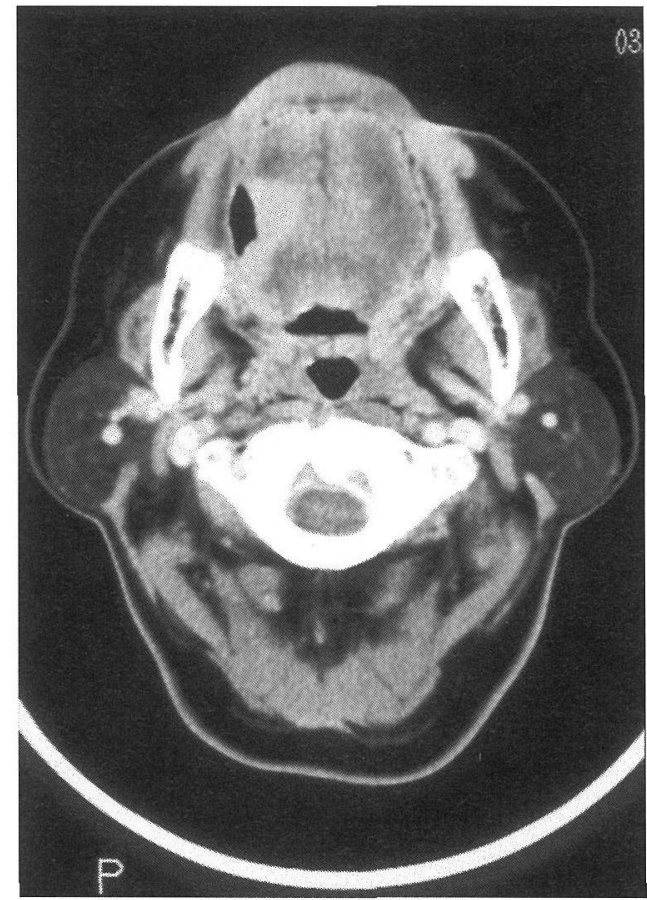

図 3 再発後の造影 $\mathrm{CT}$

舌右側, 初回手術で切除された部分の周辺に濃染される 不整な領域を認めた。

位から再発をみている。図 4 に示したように，疣状癌は 深部にまで浸潤する性質がある。今回の再発は初回手術 時に深部に浸潤した腫瘍を切除しきれていなかったため に残存腫瘍から発生したものと考えられる。したがって, 硬結を伴ら白板症では, 疮状癌も考慮に入れ, 大きく深 部までの切除が必要があるといえる。

現在, 口腔などの疮状癌の治療としては外科的切除, 放射線治療が主に行われている。口腔や喉頭の病状癌に 放射線治療を行った場合， $7 \sim 30 \%$ 症例において分化 度の低い扁平上皮癌に変化（anaplastic transformation）し たといら報告がある。しかし, Medina ら 2) の報告による と口腔の疮状癌と診断された 104 例の病理標本を再検討 したところ，20 例（19.2\%）に低分化型の扁平上皮癌の 混在を認めたことや，初期治療が外科的切除，放射線治 療のどちらの場合であっても初期治療後に局所再発した 腫瘍は扁平上皮癌が主体となっていることから，もとも と疮状癌には初期治療前から扁平上皮癌が混在している 可能性が高く，放射線の照射により扁平上皮癌化したと はいいきれないと思われる。 Ackerman"1) は，口腔の将状 癌に対して放射線治療を行った14例のうち8例に局所再 


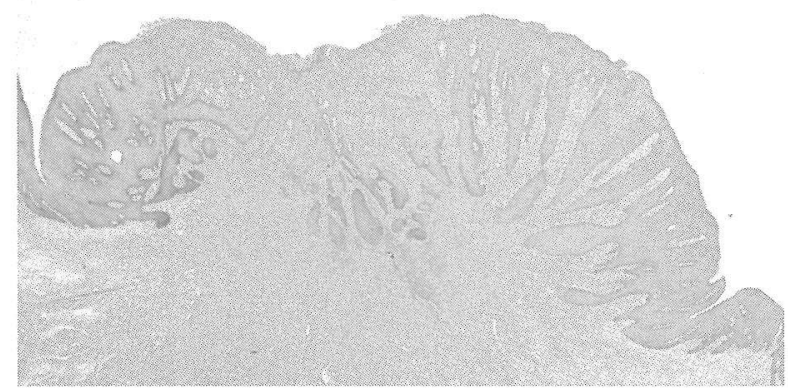

a

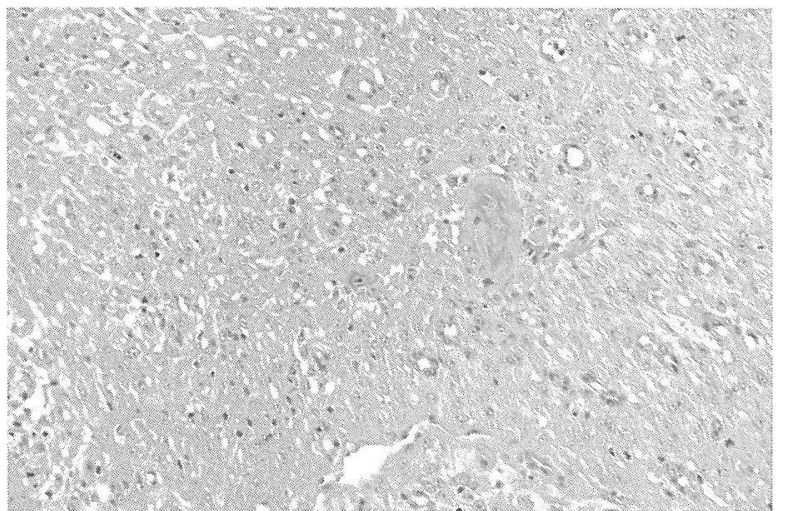

b

図 4 再発後の手術標本の HE 染色 $(\mathrm{a}: \times 10, \mathrm{~b}: \times 80)$

a. 前回の舌部分切除術によって生じた凹部分に隆起性の腫瘍を認める。乳頭は深部にまで及んでいる。

b. 腫瘍は高分化型であり過形成との鑑別は難しい.

発を認めたことから,放射線治療は病変が比較的小さく， あまり深部にまで至っていない表在性の病変にのみ有効 であると結論付けている。また Medina ら ${ }^{2)}$ は，放射線 治療老行った口腔の疻状癌 14 例の局所制御率は T1，T2 で 100\%，T3 では 75\%，T4 においては 0\% と報告し，T4 では外科的切除の局所制御率 $67 \%$ に比べるとはるかに劣 ると指摘している。 Tharp ら ${ }^{3)}$ は，頭頸部領域の疣状癌 をまとめ, 放射線治療による局所制御率は $50 \%$ 未満であ るのに対して，外科的切除による局所制御率は $75 \sim 85$ \%であり，さらに初期治療後再発した症例に対する外科 的治療の局所制御率は $80 \%$ 以上であったと報告してい る。このように，進行例での放射線療法の局所制御率が 外科的療法に比べきわめて低いことから，可能な限り外 科的療法を優先す心゙きものと考えられる。

また, 口腔病状癌に対しメトトレキセート, フルオロ ウラシル，ペプロマイシン，カルポプラチンなどを用い た化学療法を行った報告があるが4)，症例数が少なく今 後の検討を要する。

Kraus ら ${ }^{5)}$ は頭頸部領域の疮状癌 19 例に対し予防的頸 部郭清術を施行したところ，全例，所属リンパ節に転移 が認めなかったと報告しており,リンパ行転移はまれと 考えられる。また, 遠隔転移を起こした症例においても, 転移組織は疮状癌ではなく扁平上皮癌であったと報告さ れており ${ }^{3)}$ ，原発巣に混在していた扁平上皮癌が転移し たものと思われ，病状癌そのものは血行性転移もまれと 考えられる。
病状癌は低悪性度であるため, 患者の全身状態, 手術 における機能障害などを考虑して放射線照射を第一選択 とし, 再発時に外科的切除を行う治療法を推奨する報告 もあるが 6)，扁平上皮癌の混在する可能性が高いことか ら, 病理組織学的に疮状癌々診断されても扁平上皮癌々 して治療方針を決定すべきであると考える.したがって， 疫状癌に対する治療方針としては，転移が少なく外科的 治療の局所制御率が高いことから, 外科的切除が第一選 択であると考えられる。

\section{まとめ}

1）舌病状癌の 1 例を報告した。

2）㽸状癌は深部にまで浸潤する性質を持つため, 疣状 癌が疑われる症例では，大きく深部までの生検を施行す る必要があると考吕れる。

3）㾌状癌に対する治療方針としては, 外科的切除が第 一選択であると考光られる。

\section{謝辞}

診断, 治療に御協力頂いた元東京都立広尾病院耳鼻咽喉科医 長の井上都子先生, 病理部の田中道雄医長, 石川文隆医師に感 謝いたします。

\section{参考文献}

1) Ackerman LV : Verrucous carcinoma of the oral cavity. Surgery $23: 670 \sim 678,1948$.

2) Medina JE, Dichtel W and Luna MA : Verrucous-squamous 
carcinomas of the oral cavity: a clinicopathologic study of 104 cases. Arch Otolaryngol $110: 437 \sim 440,1984$.

3) Tharp ME 2nd and Shidnia $H$ : Radiotherapy in the treatment of verrucous carcinoma of the head and neck. Laryngoscope $105: 391 \sim 396,1995$.

4）濱本 泰, 新野恵司, 吉野雅也, 他: 口腔 Verrucous carcinoma の放射線治療. 日放腫会誌 $12: 307 \sim 313,2000$.

5) Kraus FT and Perezmesa $\mathrm{C}$ : Clinical and pathologic study of 105 cases involving oral cavity, larynx and genitalia. Cancer $19: 26 \sim 38,1966$.
6）須田佳人，花牟礼豊，笠野藤彦，他：鼻腔から発生した㾌 状癌（Verrucous carcinoma）の 1 例. 日耳鼻 $106: 156 \sim$ 159, 2003.

原稿受付：平成16年 4 月 16 日

原稿採択：平成 16 年 7 月 1 日

別刷請求先 : 坂本雅之

于166-8588 東京都杉並区阿佐谷北1-7-3

河北総合病院耳鼻咽喉科 